\title{
Synthesis of Nano Sulfur Particles and their Antitumor Activity
}

\section{Faten $\mathbf{Z}^{1}$, Mustafa $\mathrm{H}^{2}$ and Muayad ALD ${ }^{*}$}

${ }^{1}$ Department of chemistry, Zagazig University, Egypt

${ }^{2}$ Department of Education for pure Sciences, Diyala University, Baghdad, Iraq

\begin{abstract}
Objectives: The present study is designed to evaluate the antitumor activity of sulphur containing compounds in Nano formulations against Ehrlisch Ascites Carcinoma (EAC) in female albino mice.

Methods: Preparation of sulfur nanoparticles (S-NPs) was done throughout. Firstly, the evaluation of their composition and purity by fourier transform infrared spectrometer (FT-IR) analysis. Secondly, the shape and size of S-NPs were investigated by scanning electron microscopy (SEM) techniques in all S-NPs samples which were prepared with Tetramethylammoniumbromide (TMAB) surfactant, Then, Energy-dispersive X-ray spectroscopy (EDS) for the evaluation of their composition and purity, after that the X-Ray diffraction patterns were measured for prepared S-NPs with TMAB surfactant, and the determination of S-NPs antitumor activity against (breast carcinoma cell line (MCF7), liver carcinoma cell line (HEPG2), colon carcinoma cell line (HCT116), prostatic carcinoma cell line (PC3). Finally, determination biochemical assay of S-NPs by using female mice bearing EAC and of the assessment of liver functions and evaluation of kidney functions and determination of some heart functions in serum and hematology markers.
\end{abstract}

Results: This study revealed that S-NPs showed high strong activities in concentration $(5 \mathrm{mg} / \mathrm{kg})$ as it improvement of liver functions production compared to the positive control group, also showed the effect of S-NPs of the kidney functions, heart functions and hematology parameters in all studied groups and a significant increase in activities compared with positive control group.

Conclusion: S-NPs play an important role in improving liver functions, kidney functions and the heart functions of resulted in significantly increase activity against tumour and plays an important role in improving oxidative stress resulted in high antiproliferation activity against (MCF-7, HepG2, HCT116 and PC3) cell lines, and significantly increase with S-NPs reduced most of the hematological parameters towards the best compared to the positive control group.

Keywords: Sulfur Nanoparticles; Toxicity; Ehrlich ascites carcinoma; Viable cell count; Hematological

\section{Introduction}

Cancer still represents one of the most serious human health related problem; despite the great progress in understanding its biology and pharmacology. The usual therapeutic methods for cancer treatment are individually useful in particular situations and when combined with other remedies, they offer a more efficient treatment for tumour. Nanotechnological improvements can be used for cancer patients; because nanotechnology can be used for better cancer diagnosis, more efficient drug delivery to tumour cells, and molecular targeted cancer therapy. First of all, nanotechnology can be used for better cancer diagnosis. Secondly, nanotechnology can be used for more efficient drug [1]. In this study evaluated the antitumor activity of sulphur containing compounds in Nano formulations against Ehrlisch Ascites Carcinoma (EAC). It appears that Sulfur is an interesting element for tumour uptake because it plays an important role in cellular metabolism [2]. There are previous studies were on diallyl trisulfide (DATS) is a sulfane sulfurcontaining compound, showed the highest biological activity in HepG2 cells. This compound increased the $\mathrm{H}_{2} \mathrm{O}_{2}$ formation, lowered the thiol level and this is dependent on the presence of labile sulfane sulfur in their molecules [3]. Sulfur is an essential part of many enzymes and antioxidant molecules like glutathione and thioredoxin. Some sulfurcontaining compounds can efficiently form a line of defence against reactive oxygen and nitrogen species [4]. Some sulfur-containing antioxidant systems showed decrease the levels of harmful ROS and help to reduce intracellular protein di-sulfide bonds, which are formed as a result of increased ROS levels. Therefore, sulfur containing antioxidants is essential in the maintenance of normal well-being of the cell and health [5]. It appears that sulfane sulfur containing DATS can be bioreduced in cancer cells and dependent on the presence of labile sulfane sulfur in their molecules thereby influencing the transmission of signals regulating cell proliferation [3].

\section{Material and Methods}

\section{Chemicals}

The chemicals used for this study were taken from the following companies: Sodium thiosulfate $\left(\mathrm{Na}_{2} \mathrm{~S}_{2} \mathrm{O}_{3} .5 \mathrm{H}_{2} \mathrm{O}\right)$ (catalog 711906551208) was obtained from the British drug houses LTD (B.D.H. laboratory Chemical group) and Tetramethylammonium bromide (TMAB) $98 \%\left(\mathrm{C}_{4} \mathrm{H}_{12} \mathrm{BrN}\right)$ (catalog, 64-20-0) was obtained from Himedia laboratoriesPvt.Ltd.(India)., RPMI-1640 medium, Trypan blue, Fetal Bovine Serum, Penicillin/ Streptomycin antibiotic and Trypsin- EDTA. From Sigma Aldrich Chemical. Kits [Aspartate aminotransferase (AST), Alanine aminotransferase (ALT), Total proteins (TP), Albumin (Alb), Bilirubin, Urea, Creatinine, Creatine kinase MB (CK-MB) and lactate dehydrogenase (LDH)] were from Biodiagnostic Company, USA.

*Corresponding author: Muayad ALD, Department of chemistry, Zagazig University, Egypt, Tel: 20552364612; Email: moaedchemistry@yahoo.com

Received March 15, 2018; Accepted April 26, 2018; Published April 30, 2018

Citation: Faten Z, Mustafa H, Muayad ALD (2018) Synthesis of Nano Sulfur Particles and their Antitumor Activity J Microb Biochem Technol 10: 56-68. doi: 10.4172/1948-5948.1000397

Copyright: @ 2018 Faten Z, et al. This is an open-access article distributed under the terms of the Creative Commons Attribution License, which permits unrestricted use, distribution, and reproduction in any medium, provided the original author and source are credited. 


\section{Human tumor cell lines}

Human tumour cell lines (breast carcinoma cell line (MCF-7), liver carcinoma cell line (HEPG2), colon carcinoma cell line (HCT116), prostatic carcinoma cell line (PC3). were used in this study obtained from the American Type Culture Collection (ATCC, Minisota, U.S.A.). The tumour cell lines were maintained at the National Cancer Institute, Cairo, Egypt, by serial sub-culturing.

\section{Animals}

Adult female Swiss albino mice weigh 20-25 g was purchased Abo Rawash culture-Giza used throughout this study. The animals were housed in steel mesh cages (animal house, faculty of Science, Zagazig University) and the animals were maintained in the controlled environment of temperature, humidity, light, and fed on a commercial standard diet and tap water "ad-libitum".

\section{Ehrlich ascites carcinoma cells}

Ehrlich ascites carcinoma (EAC) cells were initially supplied from the National Cancer Institute, Cairo, Egypt (only for the first transplantation) and maintained in female Swiss albino mice [6], through serial intraperitoneal (I.P.) inoculation of $0.2 \mathrm{ml}$ of freshly drawn ascites fluid (diluted in 1:5 saline solution), each inoculum contained approximately $2.5 \times 10^{6}$ cells. This process was repeated every 10 days for keeping the strain available throughout the present study.

\section{Preparation of sulfur nanoparticles with TMAB surfactant}

In a typical reaction synthesis, sulfur nanoparticles (S-NPs) synthesized as follows: an appropriate amount of $50 \mathrm{ml}(0.80 \mathrm{M})$ Sodium thiosulfate $\left(\mathrm{Na}_{2} \mathrm{~S}_{2} \mathrm{O}_{3} \cdot 5 \mathrm{H}_{2} \mathrm{O}\right)$ dissolved in $50 \mathrm{ml}$ of distilled water and using the Ultrasonic (WiseClean) device to speed the process of solubility then transferred into $250 \mathrm{ml}$ conical flask 0.20 $\mathrm{ml}(0.02 \mathrm{M})$ of TMAB surfactant was dissolved in $20 \mathrm{ml}$ of distilled water. A mixture of Sodium thiosulfate and TMAB was prepared by combining both solutions together and stirred mechanically at 120 r.p.m. and heated in constant $40^{\circ} \mathrm{C}$ respectively. Then $40 \mathrm{ml}$ of $(1.0$ $\mathrm{M})$ hydrochloric acid solution was added to the mixture to produce sized NPs under continuous stirring. After the reaction was stopped after $45 \mathrm{~min}$, the produced yellow precipitates were collected, washed with distilled water and then dried according to the method of [7], [modified of Tetraoctylammonium bromide (TOAB) to Tetramethylammoniumbromide]. The nanoparticles were prepared in the laboratories of the Department of Chemistry, Faculty of Education for Pure Sciences, University of Diyala, Iraq.

\section{Samples characterization}

The sulfur nanoparticles (S-NPs) were characterized by Fourier Transform Infrared Spectrometer (FT-IR) using device model Shimadzu Model FT/IR-8400. A material film (S-NPs) is prepared $1.5 \mathrm{mg}$ of the solid sample is minced with $5 \mathrm{~g}$ of $\mathrm{KBr}$ or $\mathrm{CsBr}$ in an agate mortar, and a transparent disc (using a piston) is used free of abrasive and placed in the metering spectrometer. Employing a Scanning electron microscope (SEM) characterization. The shape and the morphology of the prepared S-NPs were characterized by Scanning electron microscope, the images have obtained using Inspect SEM (TESCAN veggie caechrepulic) type. A certain amount of S-NPs was taken with very little ethanol solvent (99\%) and then placed on a special platform with the device with the coating plate gold and photographed to identify and determine their forms. Also, Energy dispersive X-ray spectroscopy (EDS) Analysis, characterization In this technique, the qualitative and quantitative analysis of the components and the linear survey of the components, as well as the accuracy of the analysis of up to $0.1 \%$ and spatial accuracy of up to $20 \mathrm{~mm}$, are used to analyse the different samples and give an idea of existing elements, using Inspect (Oxford X-Max 20). The synthesized nanoparticles were characterized by EDS for the evaluation of their composition and purity and the sample is prepared by dissolving the (S-NPs) with the ethanol (99\%), then injecting it and observing the shape chart and the samples for X-Ray diffraction characterization using RigakuDmax 2500 diffractometer equipped with a graphite monochromatized $\mathrm{CuKa}$ radiation $\left(\mathrm{k}=1.5407^{\circ} \mathrm{A}\right)$ and particle size distribution in range 10-100 $\mathrm{nm}$. X-ray diffraction XRD technique was used to determine the structure and the size of the sulfur nanoparticles, $\mathrm{x}$-ray structural analysis of the obtained samples shows that the samples are sulfur nanoparticles have an orthorhombic phase with S8 structure with traces of monoclinic by applying Scherrer equation on the XRD pattern, the particle size can be calculated by $(D=K \lambda / b \cos \theta)$. Where $D$ is the mean size of crystallites $(\mathrm{nm}) \mathrm{K}$ is a crystallite shape factor a good approximation is $0.9, \lambda$ is the $\mathrm{X}$-ray wavelength , B is the full width at half the maximum (FWHM) in radians of the X-ray diffraction peak and $\theta$ is the Braggs' angle (deg) [8].

\section{MTT assay in cultured human cancer cells}

The effect of S-NPs on growth of cancer cells (MCF-7, HepG2, HCT116 and PC3 ), was assessed by MTT assay and cytotoxicity was carried out using Sulphorhodamine-B (SRB) assay following the method reported by Vichai and Kirtikara [9].

\section{Determination median lethal dose (LD 50) of sulfur nanoparticles (S-NPs)}

Approximate LD 50 of sulphur nanoparticles (S-NPs) in mice was determined according to the method of Meier and Theakston [10]. Studies carried out for determination of the median lethal dose are important to help us to assess the limit dose recommended. To determine the median lethal dose of sulphur nanoparticles (S-NPs), a group of 10 mice were injected with doses 1, 1.5, 2, 2.5, 3, 3.5, 4, 6, 8, 10 $\mathrm{mg} / \mathrm{Kg}$ of sulphur nanoparticles (S-NPs); respectively, soluble in corn oil [11]. Another group of mice containing 5 mice was injected with doses $50,100,200,500,1000,2000 \mathrm{mg} / \mathrm{Kg}$ of (S-NPs); respectively to determine the safety of sulphur nanoparticles (S-NPs).

\section{Determination dose response curve of sulphur nanoparticles (S-NPs)}

The dose response curve of synthesized sulphur nanoparticles (S-NPs) in mice was determined according to the method of Crump et al. [12]. Studies carried out for determination of the most effective dose on tumour volume and count.

\section{Experimental design}

The total number of 75 female Swiss albino mice weighing 20-25 g was divided into the three groups ( 25 mice in each group): Group (I): Negative Control: mice injected intraperitoneal (I.P.) with sterile saline for 10 days (day after day). Group (II): Positive Control (EAC bearing group): mice were injected with Ehrlich ascites carcinoma (EAC) by the concentration of $(2.5 \times 106$ cells $/ 0.3 \mathrm{ml} /$ mouse $)$ according to Amer [13], by I.P. injection once. Group (III) therapeutic group: mice were injected I.P. with S-NPs $(5 \mathrm{mg} / \mathrm{Kg})$ after EAC injection $(2 \times 106$ cells/ mouse), followed by I.P. injection of S-NPs at 3, 5, 7, 9 days of EAC injection for 10 days.

\section{Sampling and preparation}

Blood sampling: At the end of the experiment, the blood samples 
Citation: Faten Z, Mustafa H, Muayad ALD (2018) Synthesis of Nano Sulfur Particles and their Antitumor Activity J Microb Biochem Technol 10: 56-68. doi: 10.4172/1948-5948.1000397

were collected from the retro-orbital venous plexus under light ether anaesthesia. Plasma was prepared by centrifuging EDTA- blood at 3000 r.p.m. for $10 \mathrm{~min}$. Plasma samples were aliquot and stored at $-20^{\circ} \mathrm{C}$ until biochemical analysis. Serum was prepared by centrifuging blood at 4000 r.p.m. for $10 \mathrm{~min}$. Serum was aliquot and stored at $-20^{\circ} \mathrm{C}$ until biochemical analysis. EDTA vacuum tube which runs in a hematology analyser for estimating hematological parameters in experimental mice groups by using Automatic CBC analyzer (Sesmex Kx-21).

Biochemical investigations: The determination of serum alanine aminotransferase (ALT) activity were be according to the Hu et al. [14] determination of serum aspartate aminotransferase (AST) activity were being according to the Schumann et al. [15] and serum total proteins were determined using Biuret method performed by Burtis et al. [16], determination of albumin in serum was carried according to Cosgrove et al. [17], serum bilirubin was determined according to Jendrassik and Grof [18]. Also, biochemical kidney functions tests, determination of urea assay in blood was measured according to the method described by Tabacco et al. [19] and the creatinine concentration in the sample of determination of were being according to the Young and Friedman [20]. Also, heart functions tests in serum. Determination of serum creatine kinase $\mathrm{MB}(\mathrm{CK}-\mathrm{MB})$ activity were measured according to $\mathrm{Wu}$ and Bowers [21] determination of serum lactate dehydrogenase (LDH) activity were being accorded to Young and Friedman [20]. Finally; the estimating hematological parameters by using an Automatic CBC analyzer (Sesmex Kx-21).

\section{Statistical analysis}

All statistical analyses were done by a statistical for social science package "SPSS" 14.0 for Microsoft Windows, SPSS Inc. and considered statistically significant at a two-sided $\mathrm{P}<0.05$. Numerical data were expressed as mean \pm SD. The levels of markers were analysed by ANOVA but the Mann Whitney U-test was used for comparisons between independent groups [22].

\section{Results}

\section{Sulfur nanoparticles preparation (Particle synthesis)}

Quick precipitation method of sulfur nanoparticles was by redox comproportionation of $\mathrm{Na}_{2} \mathrm{~S}_{2} \mathrm{O}_{3} \cdot 5 \mathrm{H}_{2} \mathrm{O}$ in concentration $\mathrm{HCL}$ and using tetramethylammonium bromide (TMAB) as stabilizer according to equation following.

$$
\mathrm{Na}_{2} \mathrm{~S}_{2} \mathrm{O}_{3} \cdot 5 \mathrm{H}_{2} \mathrm{O} \underset{\text { Stirred at } \mathrm{T}=40^{\circ} \mathrm{C}}{\mathrm{TMAinConc} . \mathrm{HCl}} \mathrm{nm} \mathrm{S}-\mathrm{NPS}
$$

After particles prepared, the particles were centrifuged and washed extensively with water to remove any soluble impurities (such as unreacted sulfite) and then filtered. The sulfur nanoparticles were collected in good yield; the purity of the product was formed to be $99 \%$ and confirmed by FT-IR, EDS and X-Ray diffraction technique.

\section{Fourier transform infrared spectrometer characterization of sulfur nanoparticles}

(FT-IR)

The synthesized nanoparticles were characterized by FT-IR for the evaluation of their composition and purity, Figure 1 Shows the spectrum of the FT-IR analysis. It is evident from the no peaks that the product is completely pure and corresponds to sulfur element only.

\section{SEM characterization of sulfur nanoparticles}

The shape and size of S-NPs were investigated by SEM techniques, Figures $2 \mathrm{a}-2 \mathrm{c}$ show the SEM images of all S-NPs samples which were prepared with TMAB surfactant.

\section{EDS characterization of sulfur nanoparticles}

Results in Figure 3 showed that the EDS analysis of the as prepared sulfur nanoparticles had broad peak(S).

- X-ray diffraction (XRD) characterization of sulfur Nanoparticles.

The XRD analysis of the as prepared sulfur nanoparticles had broad peaks were measured for preparing sulfur nanoparticles with TMAB surfactant as shown in Figure 4. The diffraction peaks were clearly observed from the XRD of the sulfur nanoparticles located near two $(16.8 \mathrm{o}, 23.0 \mathrm{o}$, $25.9 \mathrm{o}, 31.7 \mathrm{o}$ and $37.7 \mathrm{o})$ of $2 \theta$ positions, that are well-attributed to the [S(113), S-(222), S-(027), S-(046) and S-(318)] respectively.

\section{Chemical studies on sulfur nanoparticles in vitro}

Cytotoxicity: The in vitro cytotoxic activities of sulfur nanoparticles were shown in Figure 5. Minimum Inhibitory concentrations of synthesized sulfur nanoparticles were found to be $10.7 \mathrm{ng} / \mathrm{ml}, 3.7 \mathrm{ng} /$ $\mathrm{ml}, 10.6 \mathrm{ng} / \mathrm{ml}$, and $3.34 \mathrm{ng} / \mathrm{ml}$ against MCF-7, HepG2, HCT116, and PC3 cell lines; respectively.

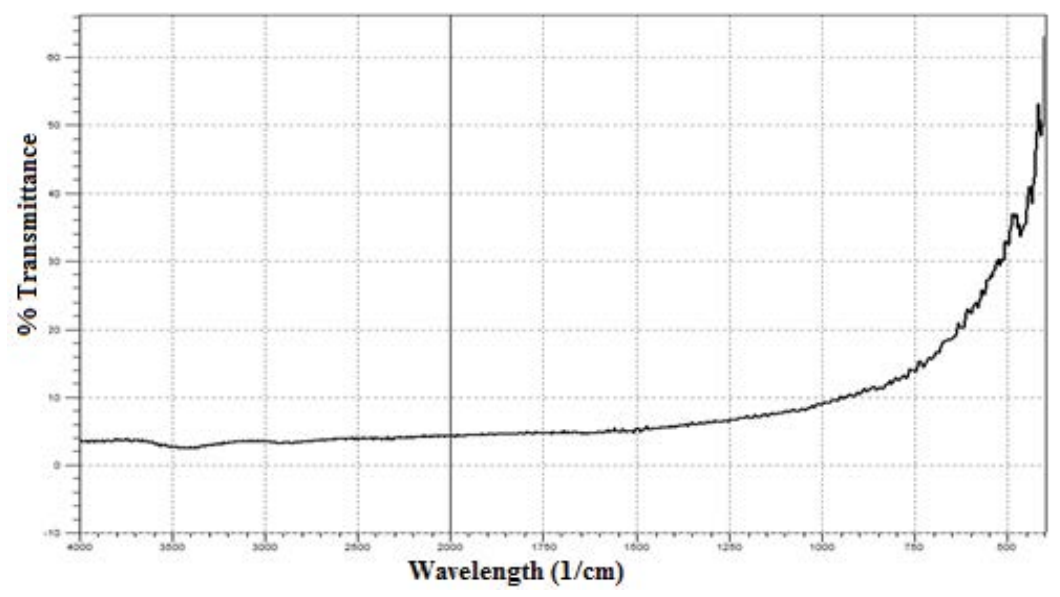

Figure 1: FT-IR spectra of sulfur nanoparticles. 


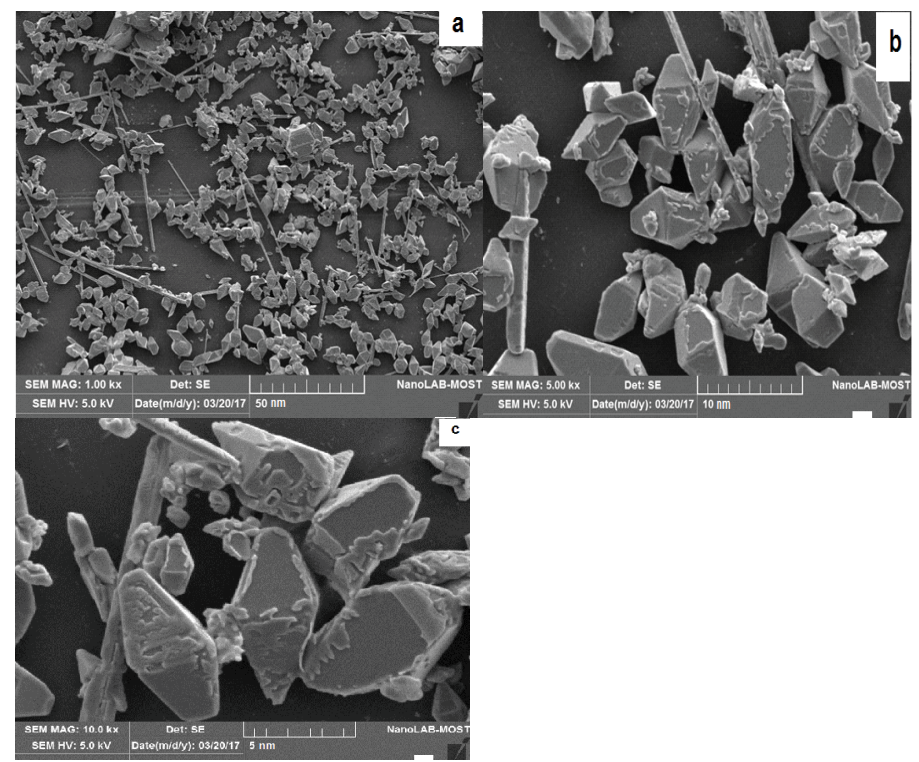

Figure 2: SEM images of the sulfur nanoparticles (a) size $50 \mathrm{~nm}$, (b) size $10 \mathrm{~nm}$ (c) size $5 \mathrm{~nm}$.

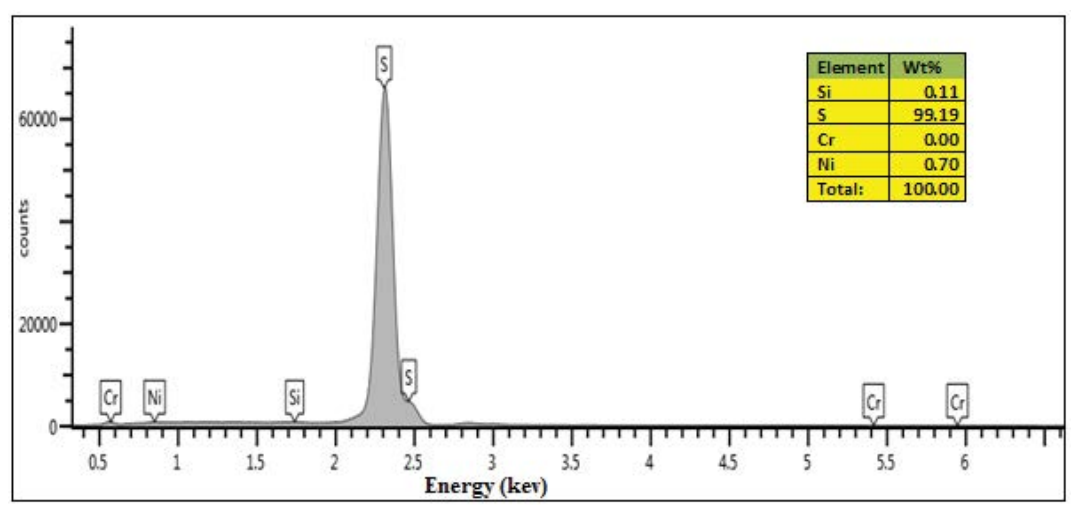

Figure 3: EDS spectrum of the sulfur nanoparticles.

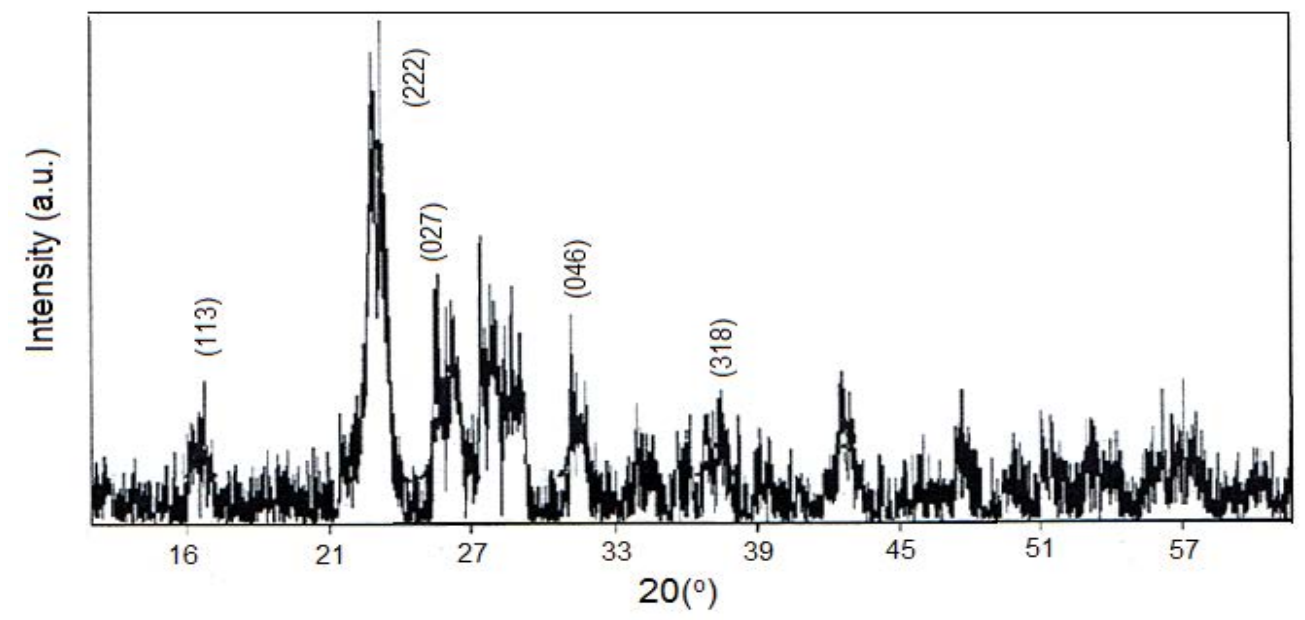

Figure 4: XRD pattern of the sulfur nanoparticles. 
Toxicity study and dose response curve: For determination of the median lethal dose (LD 50) of sulfur nanoparticles, all doses up to 200 $\mathrm{mg} / \mathrm{Kg}$ mice were found to be nontoxic as no deaths were recorded which suggests that sulfur nanoparticles may be a safe mixture. For dose-response curve it is clear that $5 \mathrm{mg} \mathrm{S}-\mathrm{NPs} / \mathrm{Kg}$ mice was found to be the most effective dose as it reduced the number of EAC cells in treated mice group up to $78 \%$ of EAC cells compared to the positive control mice group as shown in Figure $6 \mathrm{a}$ and $6 \mathrm{~b}$.

Viability count andvolume: From our results, it has been demonstrated that Sulfur nanoparticles have display anticancer activity as they decreased EAC count and EAC volume by $(82.5 \%, 73.3 \%)$; respectively in group bearing EAC $(\mathrm{P}<0.001)$ compared to positive control group as shown in Figures $6 \mathrm{a}$ and $6 \mathrm{~b}$.

Life span prolongation: The life span showed a significant increase in theraputic group by (63.63\%) compared to positive control group.

Effect on hematological parameters: In EAC-bearing mice, RBC count and packed cell volume were marked $(\mathrm{P}<0.05)$ declined, whereas total WBC count was enhanced as compared to the normal mice. Among the various white blood cells analysed, neutrophils were found to be elevated, while the lymphocytes were decremented in EACbearing mice when compared to normal mice. Sulfur nanoparticles to diseased animal have restored the above alterations to a significant extent.

There was a significant drastic fall in the hemoglobin content of the EAC control group as compared to a normal control group. Administration of sulfur nanoparticles significantly $(\mathrm{P}<0.001)$ reverted the above changes to normal (Table 1).

\section{Biochemical investigations}

Liver function tests: Data presented in Tables 2 \& 3 shown that $\mathrm{S}-\mathrm{NPs}$ administration in mice lowered AST in therapeutic $(\mathrm{p}<0.01)$, ALT $(\mathrm{p}<0.001)$, activities and bilirubin levels, $(\mathrm{p}<0.001)$ compared to positive control group, but these values are with in normal range in mice so that they show insignificant change in these markers. Data shown also insignificant increase in T.P $(\mathrm{p}<0.05)$ and albumin levels $(p<0.05)$, compared to positive control and these values are within normal range after administration of sulfur nanoparticles. Also administration of S-NPs shown significant increase in globulins by
$8.8 \%,(\mathrm{p}<0.01)$, compared to positive control group but these values are within normal range in mice so that they show insignificant changes in these parameters. Data also shown significant decreased in $A / G$ ratio in plasma levels $(\mathrm{p}<0.001)$, compared to EAC bearing tumour group, these values are within normal range after administration of S-NPs.

Kidney function tests: The mean value of urea shown significant increase in EAC bearing tumour group by $89.5 \%$, $(\mathrm{p}<0.001)$ compared to negative control group. While, their significantly decreased by $20.7 \%$ in treated group $(\mathrm{p}<0.01)$ compared to EAC bearing tumour group and these values are within normal range as in Table 4 . The mean value of creatinine shown significant increase in EAC bearing tumour group by $104 \%(\mathrm{p}<0.001)$, compared to negative control group. While, their a significantly decreased by $0.68 \%$, in treated group $(\mathrm{p}<0.01)$ compared to EAC bearing tumour group,

Heart functions: The mean value of CK-MB shown significant increase in EAC bearing tumour group by $57.9 \%,(p<0.001)$, compared to negative control group. While, their significant decreased by $15.8 \%$ in treated group $(\mathrm{p}<0.01)$ compared to EAC bearing tumour group, as shown in Table 5. Also, the mean value of LDH shown increases in EAC bearing tumour group by $41.1 \%,(\mathrm{p}<0.001)$, compared to negative control group. While, their significantly decreased by $0.12 \%$ in treated group $(\mathrm{p}<0.01)$ compared to EAC bearing tumour group and these values are within normal range.

\section{Discussion}

Cancer is a major health problem threating the life in both developed and developing countries. It is a progressive uncontrolled degenerative disease predisposed by accumulation of toxins, disturbances in hormonal and immune conditions can induce cancer [23]. Cancer cells may be more prone to the accumulation of reactive oxygen species (ROS) than normal cells; therefore increased oxidative stress can specifically kill cancer cells including Cancer Stem Cells (CSCs). In order to generate oxidative stress in various cancer cell lines [24], Ehrlich Ascities Carcinoma (EAC) is one of the commonest tumours. EAC is referred as an undifferentiated carcinoma and is originally hyper diploid, has the high Transplantable capability, noregression, they are converted to the ascites form. EAC resembles human tumours, which are the most sensitive to chemotherapy due to the fact that they are undifferentiated and that they have a rapid growth

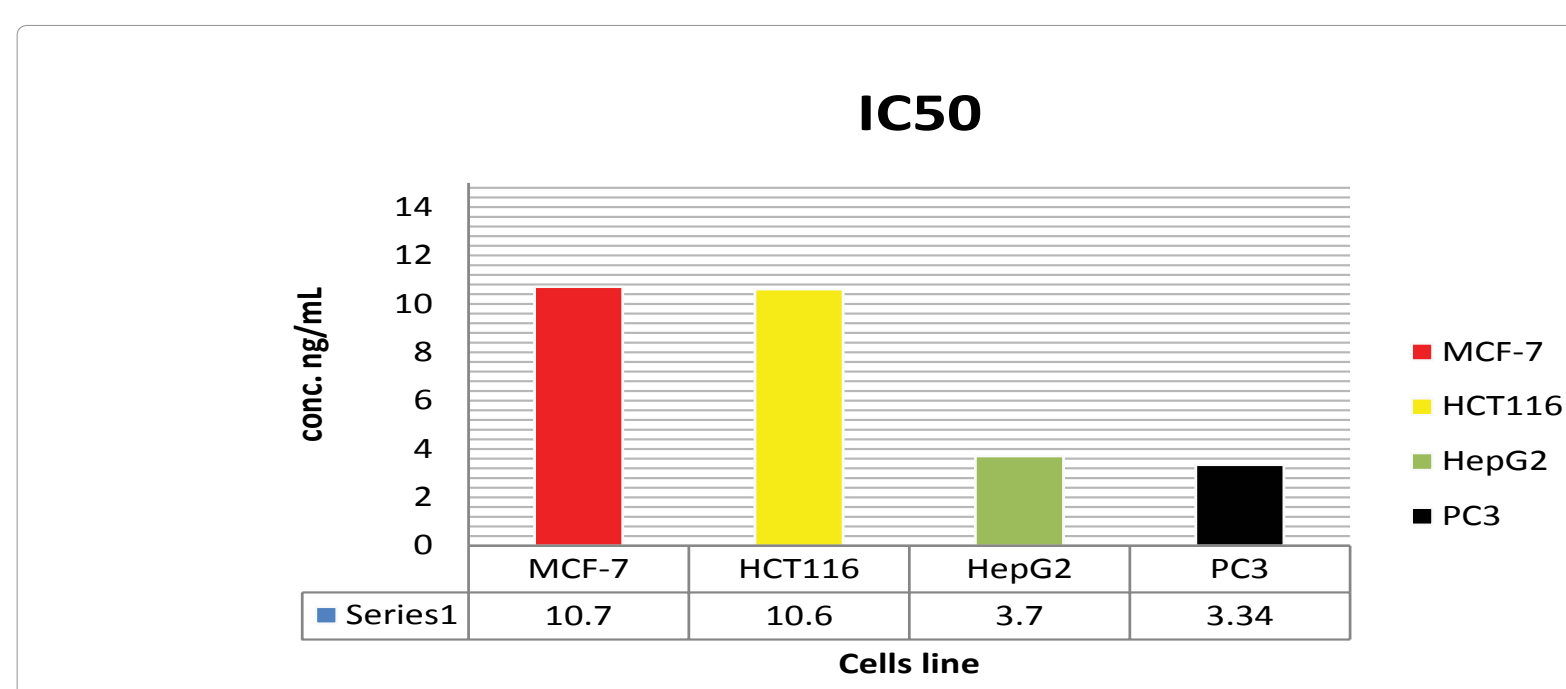

Figure 5: Antitumor activity of sulfur nanoparticles in in vitro stud. 
Citation: Faten Z, Mustafa H, Muayad ALD (2018) Synthesis of Nano Sulfur Particles and their Antitumor Activity J Microb Biochem Technol 10: 56-68. doi: 10.4172/1948-5948.1000397
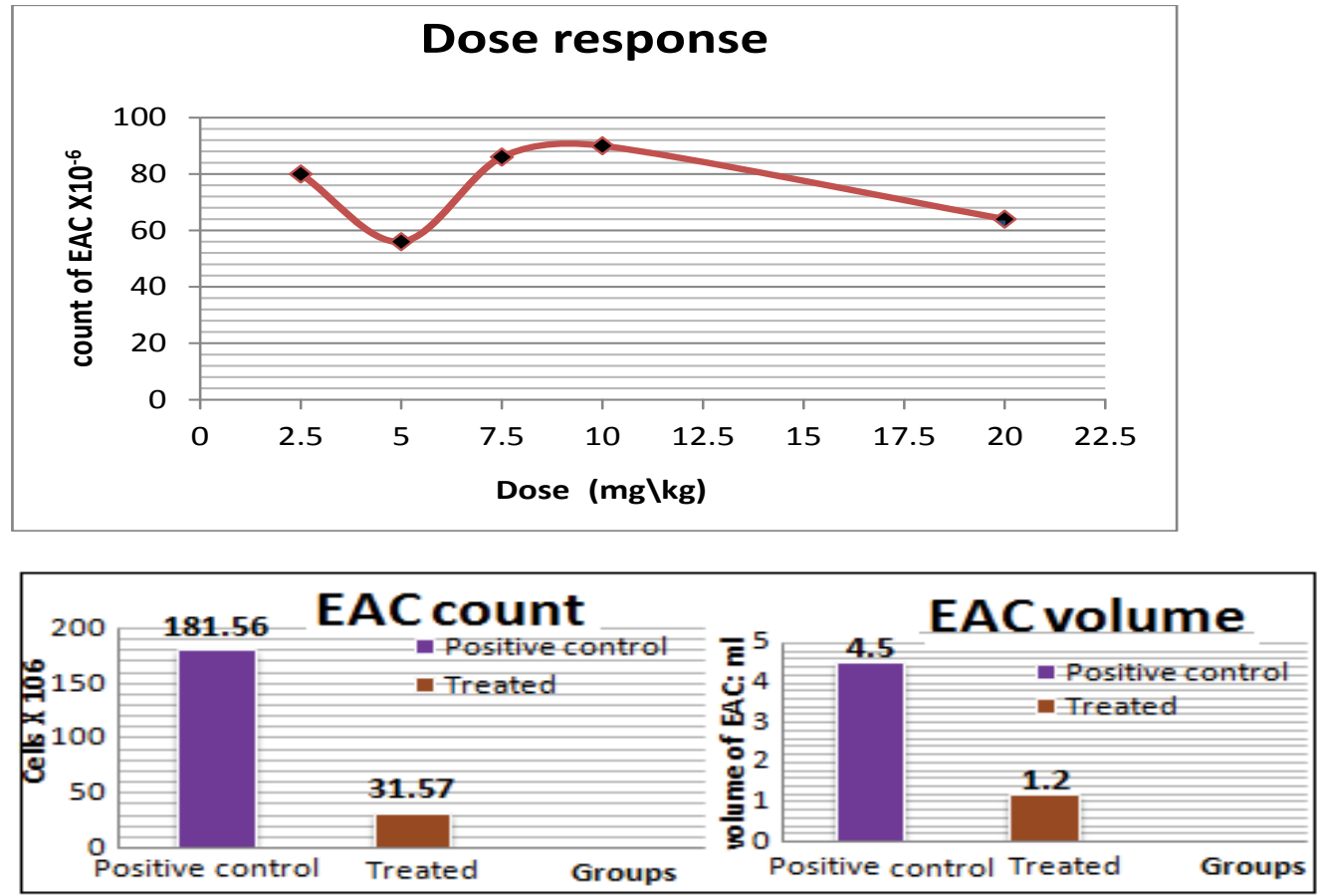

$(6, a)$

$(6, b)$

Figure 6: Dose response curve of S-N

(a) EAC count in studied groups after treatment with sulfur nanoparticles.

(b) EAC volume in studied groups after treatment with sulfur nanoparticles.

\begin{tabular}{|c|c|c|c|c|c|c|c|c|}
\hline Mice Group & $\operatorname{RBC}\left(x 10^{6}\right)$ & $\mathrm{Hb}$ g/dL & HCT g/L & MCV fL & MCH Pg & $\begin{array}{l}\mathrm{MCHC} \\
\mathrm{g} / \mathrm{dL}\end{array}$ & WBC $\left(x 10^{6}\right)$ & Neutr \\
\hline $\begin{array}{l}\text { Negative control } \\
\text { group }\end{array}$ & $8.02 \pm 0.38$ & $12.0 \pm 0.85$ & $38.24 \pm 2.4$ & $47.02 \pm 2.7$ & $14.5 \pm 1.2$ & $30.6 \pm 0.93$ & $7.85 \pm 1.66$ & $17.1 \pm 1$ \\
\hline $\begin{array}{l}\text { Positive control } \\
\text { group } \\
\% \text { Change }\end{array}$ & $\begin{array}{l}6.4 \pm 0.9 \\
20.1 \%\end{array}$ & $\begin{array}{l}7.4 \pm 0.9 \\
38.3 \%\end{array}$ & $\begin{array}{c}23.23 \pm 7.3 \\
39 \%\end{array}$ & $\begin{array}{c}46.9 \pm 2.6 \\
0.25 \%\end{array}$ & $\begin{array}{c}15.3 \pm 0.65 \\
5.5 \%\end{array}$ & $\begin{array}{c}32.2 \pm 0.54 \\
5.22 \%\end{array}$ & $\begin{array}{c}13.5 \pm 0.67 \\
71.9 \%\end{array}$ & $\begin{array}{c}42.8 \pm 3 \\
150 \%\end{array}$ \\
\hline $\begin{array}{c}\text { The group Change } \\
\%\end{array}$ & $\begin{array}{l}8.8 \pm 0.68 \\
9.7 \%\end{array}$ & $\begin{array}{c}12.8 \pm 0.48 \\
6.6 \%\end{array}$ & $\begin{array}{c}35.6 \pm 3.4 \\
6.9 \%\end{array}$ & $\begin{array}{c}46.9 \pm 1.4 \\
0.25 \%\end{array}$ & $\begin{array}{c}15.4 \pm 0.37 \\
6.2 \%\end{array}$ & $\begin{array}{c}32.0 \pm 1.17 \\
4.5 \%\end{array}$ & $\begin{array}{c}9.17 \pm 0.65 \\
16.8 \%\end{array}$ & $\begin{array}{c}33.9 \pm 2 \\
98 \%\end{array}$ \\
\hline
\end{tabular}

$-{ }^{*} P<0.01$

$-{ }^{* *} \mathrm{P}<0.001$

Table 1: Volume, Count and Hematological parameters in studied groups. Data were expressed as Mean \pm SD and percent $\%$.

\begin{tabular}{|c|c|c|c|c|c|c|}
\hline \multirow{2}{*}{ Variables } & \multicolumn{2}{|c|}{ Negative control group } & \multicolumn{2}{|c|}{ EAC bearing tumor } & \multicolumn{2}{|c|}{ Treated (S-NPs) } \\
\hline & Mean $\pm S D$. & $\%$ Change & Mean士SD. & $\%$ Change & Mean士SD. & $\%$ Change \\
\hline AST (U/I) & $197 \pm 12$ & ------ & $281 \pm 12.5^{* \star *}$ & $42.6 \%$ & $191 \pm 5.6^{* *}$ & $32 \%$ \\
\hline ALT (U/I) & $43.4 \pm 3.5$ & ------- & $87.1 \pm 3.0^{\star \star}$ & $100.6 \%$ & $42.8 \pm 1.6^{\star \star \star}$ & $50.8 \%$ \\
\hline T.P (g/dl) & $6.34 \pm 0.28$ & ------- & $4.05 \pm 0.34^{* *}$ & $36.1 \%$ & $6.75 \pm 0.84^{* * *}$ & $66.6 \%$ \\
\hline $\mathrm{Alb}(\mathrm{g} / \mathrm{dl})$ & $3.29 \pm 0.4$ & ------ & $2.11 \pm 0.4^{* \star *}$ & $35.8 \%$ & $3.42 \pm 0.2^{* *}$ & $62 \%$ \\
\hline Bilirubin (mg/dl) & $0.56 \pm 0.09$ & ------- & $0.63 \pm 0.04^{\star *}$ & $12.5 \%$ & $0.53 \pm 0.1^{* \star *}$ & $15.8 \%$ \\
\hline
\end{tabular}

Significance at ${ }^{*} \mathrm{P}<0.05,{ }^{* *} \mathrm{P}<0.01,{ }^{* * *} \mathrm{P}<0.001$

Table 2: Effect of sulfur nanoparticles on liver functions in plasma in all studied groups.

rate [25]. In this study evaluated the antitumor activity of sulphur containing compounds in Nano formulations against Ehrlisch Ascites Carcinoma (EAC) in female albino mice. Sulfur is found in every cell in the human body and is involved in a wide range of biochemical functions. Sulfur's involvement in the human body ranges from Cellular energy production/metabolism. Maintaining blood glucose levels and Antioxidant protection-scavenges or neutralizes free radicals and recycles oxidized antioxidants and Blood flow-produces both blood clotting factors as well as anticoagulants and Proper immune [26]. Nanosize sulfur particles have many important applications like in pharmaceuticals. It appears that sulfane sulfur containing DATS can be bio reduced in cancer cells to hydroperthiol that leads to $\mathrm{H}_{2} \mathrm{O}_{2}$ generation, thereby influencing the transmission of signals regulating cell proliferation and apoptosis [4]. 


\begin{tabular}{|c|c|c|c|c|c|c|}
\hline \multirow{2}{*}{ Variable } & \multicolumn{2}{|c|}{ Negative control group } & \multicolumn{2}{|c|}{ EAC bearing tumor } & \multicolumn{2}{|c|}{ Treated (S-NPs) } \\
\hline & Mean $\pm S D$ & $\%$ Change & Mean $\pm S D$ & $\%$ Change & Mean $\pm S D$ & $\%$ Change \\
\hline Globulins (g/dl) & $3.04 \pm 0.43$ & ------ & $1.94 \pm 0.65^{\star \star \star}$ & $36.1 \%$ & $3.31 \pm 0.91^{* * *}$ & $70.6 \%$ \\
\hline A/G Ratio & $1.11 \pm 0.28$ & ------ & $1.2 \pm 0.73^{\star * *}$ & $8.1 \%$ & $1.1 \pm 0.33^{\star * *}$ & $8.3 \%$ \\
\hline
\end{tabular}

Significance at ${ }^{*} \mathrm{P}<0.05,{ }^{* *} \mathrm{P}<0.01,{ }^{* * *} \mathrm{P}<0.001$

Table 3: Effect of sulfur nanoparticles on globulins and A/G ratio in plasma in all studied groups.

\begin{tabular}{|c|c|c|c|c|c|c|}
\hline \multirow{2}{*}{ Variable } & \multicolumn{2}{|c|}{ Negative control group } & \multicolumn{2}{|c|}{ EAC bearing tumor } & \multicolumn{2}{|c|}{ Treated (S-NPs) } \\
\hline & Mean $\pm S D$ & \% Change & Mean士SD & $\%$ Change & Mean $\pm S D$ & $\%$ Change \\
\hline $\begin{array}{l}\text { Urea } \\
(\mathrm{mg} / \mathrm{dl})\end{array}$ & $28.96 \pm 1.6$ & ------ & $54.88 \pm 2.6^{* *}$ & $89.5 \%$ & $34.9 \pm 3.6^{* * *}$ & $36.4 \%$ \\
\hline $\begin{array}{l}\text { Creat } \\
(\mathrm{mg} / \mathrm{dl})\end{array}$ & $0.346 \pm 0.03$ & ------ & $0.708 \pm 0.08^{* * *}$ & $104 \%$ & $0.343 \pm 0.06^{* *}$ & $51.5 \%$ \\
\hline
\end{tabular}

Significance at ${ }^{*} \mathrm{P}<0.05,{ }^{* *} \mathrm{P}<0.01,{ }^{* *} \mathrm{P}<0.001$

Table 4: Effect of sulfur nanoparticles on kidney functions in all studied groups.

\begin{tabular}{|c|c|c|c|c|c|c|}
\hline \multirow{2}{*}{ Variable } & \multicolumn{2}{|c|}{ Negative control group } & \multicolumn{2}{|c|}{ EAC bearing tumor } & \multicolumn{2}{|c|}{ Treated (S-NPs) } \\
\hline & Mean $\pm S D$. & $\%$ Change & Mean士SD. & $\%$ Change & Mean士SD. & $\%$ Change \\
\hline $\begin{array}{l}\text { CK-MB } \\
\text { ( U/L ) }\end{array}$ & $22.2 \pm 0.5$ & ------ & $35.1 \pm 2.9^{* * *}$ & $57.9 \%$ & $25.8 \pm 2.9^{\star * \star}$ & $26.4 \%$ \\
\hline $\begin{array}{l}\text { LDH } \\
\text { ( U/L ) }\end{array}$ & $1620 \pm 103$ & ------ & $2287 \pm 132^{\star * *}$ & $41.1 \%$ & $1622 \pm 77^{\star * *}$ & $29 \%$ \\
\hline
\end{tabular}

Significance at ${ }^{*} P<0.05,{ }^{* *} P<0.01,{ }^{* * *} P<0.001$

Table 5: Effect of sulfur nanoparticles on heart functions in all studied groups.

Chemical characterization of sulfur nanoparticles was done by some methods to determine purity, composition and the structure of these particles.

These sulfur nanoparticles were analysed using the IR spectrum to confirm the purity. They were characterized by FT-IR for the evaluation of their composition. Figure 1 shows the spectrum of the FT-IR analysis. It is evident from the no peaks that the product is completely pure and corresponds to sulfur element only. These results are in agreement with Awwad et al. [27]. Who stated the FT-IR analysis was carried out to identify the possible biomolecules responsible for the capping and stabilization of sulfur nanoparticles, which were identical in terms of purity and stability.

Also, show the SEM images of sulfur particle synthesize by $1 \mathrm{M}$ of $\mathrm{HCl}$ catalyzed in the presence of TMAB surfactants. The shape and size of S-NPs were investigated by SEM techniques, Figures $2 a-2 c$ to show the SEM images of all S-NPs samples more regular shape. The SEM micrographs showed of the size distribution is unanimous nano-scale which the scale range of sulfur nanoparticles is $\mathbf{5 - 5 0 ~ n m a s ~ s h o w ~ F i g u r e s ~}$ 2a-2c other studies revealed some results using (SEM) [7], by Analysis of scanning electron microscope (SEM) Sulfur nanoparticles.

The synthesized nanoparticles were characterized by EDS for the evaluation of their composition and purity, Figure 3 shows the spectrum of the EDS analysis. It is evident from the peaks that the product is highly pure and corresponds to sulfur element only. Also, showed that the EDS analysis of the as prepared sulfur nanoparticles had broad peak. Similar studies [6], Revealed by EDS analysis sulfur nanoparticles that the product is highly pure.

The XRD analysis of the as prepared sulfur nanoparticles had broad peaks were measured for preparing sulfur nanoparticles with TMAB surfactant as shown in Figure 4 . The diffraction peaks were clearly observed from the XRD of the sulfur nanoparticles located near two $(16.8 \mathrm{o}, 23.0 \mathrm{o}, 25.9 \mathrm{o}, 31.7 \mathrm{o}$ and $37.7 \mathrm{o})$ of $2 \theta$ positions, that are wellattributed to the [S-(113), S-(222), S-(027), S-(046) and S-(318)]; respectively. Synthesized sulfur nanoparticles are well-crystalline, the position and the relative intensity of the diffraction peaks match well with the standard monoclinic phase sulfur diffraction pattern [28]. There is no other phase found, which means that phase pure monoclinic sulfur was prepared under these experimental conditions, and a similar study was revealed by XRD analysis Sulfur nanoparticles [8].

\section{The goal of the in vitro study was to explore the mechanism underlying}

Sulfur nanoparticles-induced cell death in human MCF-7, HepG2, HCT116 and PC 3 cell lines, here, we report that treatment with sulfur nanoparticles inhibited cell proliferation and viability. To investigate the effect of sulfur nanoparticles on cells viability of MCF-7, HepG2, HCT116 and PC 3 cells, cells were treated with or without different concentrations of sulfur nanoparticles for $48 \mathrm{~h}$. Our data showed that sulfur nanoparticles significantly decreased cells viability of treated MCF-7, HepG2, HCT116, and PC3 cells as confirmed by MTT assay as in Figure 5. The proliferation of MCF-7, HepG2, HCT116 and PC3 cells was significantly inhibited by sulfur nanoparticles at $(10.7 \mathrm{ng} / \mathrm{ml}$, $3.7 \mathrm{ng} / \mathrm{ml}, 10.6 \mathrm{ng} / \mathrm{ml}$, and $3.34 \mathrm{ng} / \mathrm{ml}$ ); respectively. Indicating antiproliferation activity of sulfur nanoparticles on these cell lines and raising the possibility that sulfur nanoparticles might be a potential chemo-preventive or therapeutic agent.

Those effective doses showed no cytotoxic effects on different cell lines [29], other studies revealed some results using a sulfane sulfurcontaining compound, showed the highest biological activity in HepG 2 cells. This compound produced the strongest inhibition of cell proliferation [30].

The acute toxicity was estimated by intraperitoneal administration of the sulfur nanoparticles to determine the median lethal dose (LD 50). Our results revealed that, doses up to $200 \mathrm{mg} / \mathrm{kg}$ in mice were may be considered safe for sulfur nanoparticles where no mortality was observed and mice were healthy and active during the observation period. Also, it was found that $5 \mathrm{mg} / \mathrm{kg}$ was considered to be the most effective dose causes a reduced in count and volume of EAC concentrations other. A similar study [31], was conducted using for sulfur nanoparticles has 
been given orally to the rabbits at a concentration of $2000 \mathrm{mg} / \mathrm{kg}$ body weight ( 3 animals/group) was considered safe for sulfur nanoparticles. Those toxicity effects of toxicants and therapeutic agents are dosedependent [32].

A dose-response curve is done to know which is the most effective dose of sulfur nanoparticles on the reduction of the EAC cell count by (78\%) as in Figure 6, the dose response curve for these S-NPs demonstrated that most effective dose was found to be $5 \mathrm{mg} /$ $\mathrm{kg}$. Then, these S-NPs were tested in mouse models (EAC model) to investigate the anti-tumour, anti-oxidant and anti-apoptotic activities. While at non-cytotoxic doses S-NPs is eco-friendly and clinical trials show no alarming toxic effects on eukaryotes [33]. Dose-response curve is a simple $\mathrm{x}-\mathrm{y}$ graph relating the magnitude of a stressor such as, concentration of a pollutant, the amount of a drug, temperature, intensity of radiation to the response of the receptor organism under study, the response may be a physiological or biochemical response or even death [34].

Study effect of S-NPs on volume and viable EAC cell count in studied groups. The mean values of EAC volume and count were found to be $4.5 \pm 0.5 \mathrm{ml}$ and $(181.3 \pm 11.3)^{*} 106$ cells $/ \mathrm{ml}$ in EAC bearing tumour group, while treated group were demonstrated a significant decrease in EAC volume by $73.3 \%$ and significant reduction in EAC cells count by $(82.5 \%)$, compared to EAC bearing tumour group, $(\mathrm{p}<0.001)$. Reduction of tumour volume and viable cell count of tumour-bearing mice, tumour cell growth inhibition determined the potency of an anticancer agent [35]. When anticancer agents in vivo are used for treatment in cancer cell population large changes may occur in the cell and in result of that many cells are killed by the treatment induction of apoptosis in cancer cells is one of the goals of anticancer potential of any drug [36].

As to life span prolongation (T/C\%) in treating a group with S-NPs the life of treated animals was prolonged by $163.63 \%$ compared to the positive control group.

It is apparent that S-NPs increased the RBC cells count and hemoglobin content and decreased the WBC cells count to the normal level in therapeutic group and also note changes in the a components of the other which illustrate significant increase in RBC cells count by $9.7 \%$ , Hb content by $6.6 \%$, HCT content by $6.9 \%$, MCV content by $0.25 \%$, $\mathrm{MCH}$ content by $6.2 \%, \mathrm{MCHC}$ content by $4.5 \%$ and significant decrease in WBC cells count by $16.8 \%$, Neutrophil cells count by $98 \%$, Lymphocyte cells count by $40.5 \%$ and platelet count by $10.9 \%$ in therapeutic group compared to positive control group $\left({ }^{\star} \mathrm{P}<0.05\right),\left({ }^{\star \star} \mathrm{P}<0.001\right)$. This result supports the suitability of the sulfur nanoparticles as an anticancer agent which indicates that sulfur nanoparticles has a protective action on the homeopathic system. Results in the present study were resembles as recorded by Pandya et al. [37]. One of the major problems in cancer chemotherapy is myelosuppression, followed by anemia due to the reduction of $\mathrm{RBC}$ and hemoglobin content. This is probably owing to thedeficiency of iron in a hemolytic or myelopathic condition [38]. Progression of tumor was accompanied by hematological changes compared to normal gradual decrease in hemoglobin content, RBC count and gradual increase in leukocytes [39], which was also observed in control mice. The RBC count was almost reversed back to normal range on the treatment of sulfur nanoparticles in EAC bearing mice. It also improves the WBC level efficiency. The hemoglobin level was in the near normal range in the therapeutic group. Recovery of the hematological parameters like hemoglobin content, RBC and WBC cells counts in the experimental mice indicates the protective action of sulfur nanoparticles on the hemopoietic system and TIS certainly ratios that sulfur nanoparticles possess pronounced anticancer activity with a little or no host toxic effect [40].

To evaluate the protective effect of sulfur nanoparticles on liver functions in all studied groups in AST, ALT, Bilirubin, T.P, Albumin, Globulins and $A / G$ ratio concentration level were estimated, showed AST in therapeutic $(\mathrm{p}<0.01)$, ALT $(\mathrm{p}<0.001)$, activities and bilirubin level, $(\mathrm{p}<0.001)$ compared to positive control group, but these values are within normal range in mice so that they show insignificant changes in these markers. Data shown also insignificant increase in T.P $(\mathrm{p}<0.05)$ and albumin level $(\mathrm{p}<0.05)$, compared to positive control and these values are within normal range after administration of sulfur nanoparticles .Also administration of S-NPs shown significant increase in globulins by $8.8 \%,(\mathrm{p}<0.01)$, compared to positive control group, but these values are within normal range in mice so that they show insignificant change in these parameters. Data also shown significant decreased in $A / G$ ratio in plasma levels $(p<0.001)$, compared to EAC bearing tumour group, and these values are within normal range after administration of S-NPs. These results are due to free radical released from oxidative stress caused by tumour growth which lead to DNA and tissue damage which result in changes in membrane permeability and metabolism disturbances causing elevation of the enzyme after released from mitochondria which are in agreement with Abd El-Aziz et al. [40]; who reported that Liver damage induced by tumor cells generally reflects disturbances in liver cell metabolism, which lead to characteristic changes in serum enzyme activities. The increased levels of AST in serum may be interpreted as a result of liver damage or as changes in membrane permeability indicating the severity of hepatocellular damage by EAC. As the serum of AST is a clinical indicator of tumour-induced toxicity. AST or ALT activities are a valuable aid primarily in the diagnosis of liver disease. However, when body tissue or an organ such as the liver or heart is diseased or damaged, additional AST and ALT are released into the bloodstream, causing activities of the enzyme to rise. Therefore, the amount of AST and ALT in the blood is directly related to the extent of the tissue damage [41]. Liver is the most important key organ in the metabolism, detoxification and secretory functions in the body and it is highly affected primarily by toxic agents that why we studied the following parameters which are found to be of great importance in the assessment of liver damage. Aspartate aminotransferase (AST) enzyme, Alanine aminotransferase (ALT) enzyme, Total protein (T.P), Albumin (Alb) and Bilirubin is found mainly in the liver, but also found in red blood cells, heart cells, muscle tissue and other organs, such as the pancreas and kidneys [42]. Bilirubin, another substance commonly measured in the blood to detect liver disease, is produced from the breakdown of red blood cells. A normal bilirubin level is maintained as the liver continually removes bilirubin from the bloodstream for further processing. If the liver is impaired, however, bilirubin is not removed, and the level in the bloodstream will rise [43]. Serum albumins are important in regulating blood volume by maintaining the oncotic pressure (also known as colloid osmotic pressure) of the blood compartment [44].

To evaluate the protective effect of sulfur nanoparticles on kidney functions in all studied groups in urea and creatinine concentration levels was estimated and the mean value of urea showed significant increase in EAC bearing tumor group by $89.5 \%$, $(\mathrm{p}<0.001)$, compared to negative control group. While, their significantly decreased by $20.7 \%$, in treated group $(\mathrm{p}<0.01)$ compared to EAC bearing tumour group and these values are within normal range. The mean value of creatinine showed significant increase in EAC bearing tumour group by $104 \%,(p<0.001)$, compared to negative control group. While, their a significantly decreased by $0.68 \%$, in treated group $(\mathrm{p}<0.01)$, compared 
to EAC bearing tumour group .Also, the kidneys are important because they keep the composition, or make up, of the blood stable, which lets the body functions like: prevent the build-up of wastes and extra fluid in the body, keep levels of electrolytes stable, such as sodium, potassium, and phosphate, make hormones that help, regulate blood pressure, make red blood cells and bones stay strong [45]. Liver and kidney toxicity induced during tumour growth may be due to the excessive production of ROS that leads to oxidative damage [46]. It has been established that ROS play an important role in inflammatory conditions by interacting with pro-inflammatory cytokines. The over-produced proinflammatory cytokines may lead to inflammation, enhance systemic inflammatory stress and also pro-mote the deterioration of cardiac and/ or renal dysfunctions [47].

To evaluate the protective effect of sulfur nanoparticles on heart functions in all studied groups in $\mathrm{CK}-\mathrm{MB}$ and $\mathrm{LDH}$ concentration levels was estimated and the mean value of CK-MB showed significant increase in EAC bearing tumour group by $57.9 \%,(\mathrm{p}<0.001)$, compared to negative control group. While, theirs significant decreased by $15.8 \%$, in treated group $(\mathrm{p}<0.01)$ compared to EAC bearing tumour group. Also, the mean value of $\mathrm{LDH}$ shown increased in EAC bearing tumour group by $41.1 \%$, $(\mathrm{p}<0.001)$ compared to negative control group. While, their significantly decreased by $0.12 \%$, in treated group $(\mathrm{p}<0.01)$ compared to EAC bearing tumour group and these values are within normal range. These results in were in agreement with Maghamiour and Safaie [48]. Who reported that elevated CK-MB fraction is seen in prostatic carcinoma and other underlying malignancy, such as breast cancer. Injury or stress to muscle tissue, the heart, or the brain can be associated with increased total CPK levels due to CPK leakage into the circulation. Increase in any particular type of CPK would define the type of damaged tissue. Increased serum levels of CK isoenzymes variously signal heart, brain, or skeletal muscle damage. They may also be markers for advanced tumours with poor prognosis [49]. Which shown that CK-MB level measured by mass assay, is elevated significantly in serum on day I after myocardial infarction in rats, induced by coronary artery ligation. A significant elevation in the level of CK-MB has been observed in the heart effluent during myocardial ischemia and reperfusion in isolated rat hearts [50], during recent years, CK-MB activity assays have been replaced by CK-MB mass assays which measure the protein concentration of CK-MB, rather than its catalytic activity. Enzyme immunoassays have become the choice for measuring $\mathrm{CK}-\mathrm{MB}$ in the laboratory because analytical interferences which lead to false positive test results are less frequent.

\section{Conclusion}

These results are due to that the significant increase in LDH value resulted from heart tissue damage caused by tumour growth which were in agreement with Radenkovic et al. [51]. Who reported that activity of LDH in tumour tissue along with mammographic characteristics could help in defining aggressive breast cancers as the elevation in $\mathrm{LDH}$ value was suggested for the same explanation. Free radical leads to oxidative stress and ROS generation which cause cardiac tissue damage releasing this enzyme and elevating its level in the blood stream [52].

\section{References}

1. Aliosmanoglu A, Basaran I (2012) Nanotechnology in cancer treatment. J Nanomed Biotherapeut Discov 2: 107.

2. Porras I (2011) Sulfur-33 nanoparticles: A monte carlo study of their potential as neutron capturers for enhancing boron neutron capture therapy of cancer. App Rad Iso 69: 1838-1841.]

3. Iciek M, Kwiecień I, Chwatko G, Sokołowska-Jeżewicz M, Kowalczyk-Pachel D et al., (2012) The effects of garlic-derived sulfur compounds on cell proliferation caspase 3 activity, thiol levels and anaerobic sulfur metabolism in human hepatoblastoma HepG2 cells. Cell Biochem Func 30: 198-204.]

4. Rezk BM, Haenen GRMM, van der Vijgh WJF, Bast A (2004) Lipoic acid protects efficiently only against a specific form of peroxynitrite-induced damage. J BiolChem 279: 9693-9697.

5. Mukwevho E, Ferreira Z, Ayeleso A (2014) Potential role of sulfur-containing antioxidant systems in highly oxidative environments. Molecules 19: 1937619389.

6. Salem FS, Badr MO, Neamat-Allah AN (2011) Biochemical and pathological studies on the effects of levamisole and chlorambucil on Ehrlich ascites carcinoma bearing mice. Vet Italiana 47: 89-95.

7. Suleiman M, Al-Masri M, Al Ali A, Aref D, Hussein A et al., (2015) Synthesis of nano-sized sulfur nanoparticles and their antibacterial activities. J Mater Environ Sci 6: 513-518?

8. Holzwarth U, Gibson N (2011) The Scherrer equation versus the 'DebyeScherrer equation'. Nat Nanotech 6: 534.

9. Vichai V, Kirtikara K (2006) Sulforhodamine B colorimetric assay for cytotoxicity screening. Nat Protoc 1: 1112-1116.

10. Meier J, Theakston RDG (1986) Approximate LD50 determinations of snake venoms using eight to ten experimental animals. Toxicon 24: 395-401.]

11. Essam AM (1986) Effects of some biologically active compounds on experimental tumor cells (in mice). Thesis, Ain-Shams University 37-38.

12. Crump KS, Hoel DG, Langley CH, Peto R (1976) Fundamental carcinogenic processes and their implications for low dose risk assessment. Can Res 36 2973-2979.

13. Amer YE, (1986) Studies on the effect of dietary magnesium and manganese on experimental tumor cell (in mice).Thesis, Ain-Shams University: 35.

14. Hu S, Balakrishnan A, Bok RA, Anderton B, Larson PE et al., (2011) 13 C-pyruvate imaging reveals alterations in glycolysis that precede C-Mycinduced tumor formation and regression. Cell Metabo 14: 131-142.

15. Schumann G, Bonora R, Ceriotti F, Ferard, G, Ferrero CA, et al., (2002 IFCC primary reference procedures for the measurement of catalytic activity concentrations of enzymes at $37 \mathrm{C}$. Part 4 . Reference procedure for the measurement of catalytic concentration of alanine aminotransferase. Clin Chem Lab Med 40: 718-724.

16. Burtis CA, Ashwood ER, Bruns DE (2012) Tietz textbook of clinical chemistry and molecular diagnostics-e-book. Elsevier Health Sciences.

17. Cosgrove D, Meehan DT, Delimont D, Pozzi A, Chen X, et al., (2008) Integrin a1ß1 regulates matrix metalloproteinases via P38 mitogen-activated protein kinase in mesangial cells: Implications for Alport syndrome. Am J Pathol 172: 761-773.

18. Jendrassik L, Grof $P$ (1938) Colorimetric method of determination of bilirubin Biochem Z 297: 81-82.

19. Tabacco A, Meiattini F, Moda E, Tarli P (1979) Simplified enzymic/colorimetric serum urea nitrogen determination. Clin Chem 25: 336-337.

20. Young DS, Friedman RB (2001) Effects of disease on clinical laboratory tests (Vol.1). Amer Assn for Clin Chem.

21. Wu AH, BowersGN (1982) Evaluation and comparison of immunoinhibition and immunoprecipitation methods for differentiating MB and BB from macro forms of creatine kinase isoenzymes in patients and healthy individuals. Clin Chem 28: 2017-2021.

22. Schwartz BM, Wilson JH, Goff DM (2018) Aneasyguide to research design \& SPSS. SAGE Publications.

23. El BialyBE, Ragaa A, Khaled SH, Hamza HA (2017) Cytotoxic effect of biosynthesized silver nanoparticles on Ehrlich ascites tumor cells in mice. Int $J$ Pharmacol 13: 134-144.

24. Yilmazer A (2018) Cancer cell lines involving cancer stem cell populations respond to oxidative stress. Biotech Rep 17: 24-30.

25. Ozaslan M, Karagoz ID, Kilic IH, Guldur ME (2011) Ehrlich ascites carcinoma. Afr J Biotech 10: 2375-2378.

26. HosonoT, Fukao T, Ogihara J, Ito Y, Shiba H, et al. (2005) Diallyltrisulfi-de suppresses the proliferation and induces apoptosis of human colon cancer cells through oxidative modification of $\beta$-tubulin. J Biol Chem 280: 41487-41493. 
Citation: Faten Z, Mustafa H, Muayad ALD (2018) Synthesis of Nano Sulfur Particles and their Antitumor Activity J Microb Biochem Technol 10: 56-68. doi: 10.4172/1948-5948.1000397

27. Awwad AM, Salem NM, Abdeen AO (2015) Novel approach for synthesis sulfur (S-NPs) nanoparticles using Albiziajulibrissin fruits extract. Adv Mat Lett 6: 432-435

28. Deane K, Smith, Ron J (2018) Joint commission on powder diffraction standards powder diffraction file, inorganic phase. international center for diffraction data. PA, USA. JCPDS No. 08247: 410.

29. Lin CH, Lu WC, Wang CW, Chan YC, Chen MK (2013) Capsaicin induces cell cycle arrest and apoptosisin human KB cancer cells. BMC Complem Altern Med 13: 46.

30. Amruthra NJ, Preetamraj JP, Saravanan S, Lebel LA (2014) In vitro studies on anticancer activity of capsaicinoids from capsicum Chinensea against human hepatocellular carcinoma cells. Int J Pharm PharmSci 6: 254-558.

31. Choudhury SR, Basu A, Nag T, Sengupta K, Bhowmik M, Goswami A (2013) Expedi-tion of in vitro dissolution and in vivo pharmacokinetic profiling of sulfur nanoparticles based antimicrobials. Environ Tox Pharm 36: 675-679.

32. Castleman M (2001) The new healing herbs: the classic guide to nature's best medicines featu-ring the top 100 time-tested herbs. Rodale.

33. SudarsanBaskar PP, Chandrababu K (2015) Anti-microbial studies using sulphur nano particles on dandruff causing malassezi yeasts. In Proceedings of the World Congress on Engineering.

34. Altshuler B (1981) Modeling of dose-response relationships. Environ Heal Persp 42: 23?

35. Perveen R, Islam F, Khanum J, Yeasmin T (2012) Preventive effect of ethano extract of AlpiniacalcarataRosc on Ehrlich's ascitic carcinoma cell induced malignant ascites in mice. Asian Pacific J Trop Med 5: 121-125.

36. Denicourt C, Dowdy SF (2004) Targeting apoptotic pathways in cancer cells Sci 305: 1411-1413.

37. Pandya NB, Tigari P, Dupadahalli K, Kamurthy H, Nadendla RR (2013) Antitumor and antioxidant status of Terminaliacatappa against Ehrlich ascites carcinoma in Swiss albino mice. Ind J Pharm 45: 464.

38. Anatole PC (2014) In vivo anticancer activity of vanillin, benzophenone and acetophenonethiosemicarbazones on Swiss albino mice. J Coastal Life Med 2: 811-816.

39. Muhammad RH, Muhammad AA, Muhammad RK (2011) Inhibition of Ehrlich's ascites carcinoma by ethyl acetate extract from the flower of Calotropisgigantia L. in mice. J Appl Biomed 8: 47-54.

40. Abd El-Aziz AF, Hefni ME, Shalaby AM (2014) Inhibitory effects of Rosemary (Rosmarinus of ficinalis L.) on Ehrlich ascites carcinoma in mice. Intern J Curr Res Acad Revi 2: 330-357.
41. Huang XJ, Choi YK, Im HS, Yarimaga O, Yoon E and Kim HS (2006) Aspartate amino trans- ferase (ast/got) and alanine aminotransferase (alt/gpt) detection techniques. Sensors 6: 756-782.

42. Baligar NS, Aladakatti RH, Ahmed M, Hiremath MB (2014) Evaluation of acute toxicity of neem active constituent, nimbolide and its hepatoprotective activity against acute dose of carbon tetrachloride treated albino rats. Intern J Pharm Sci Res 5: 3455

43. Kao T, Chou CH, Wang CC, Chou CC, Hu J, et al., (2012) Associations between serum total bilirubin levels and functional dependence in the elderly. Intern Med J 42: 1199-1207

44. Farrugia A (2010) Albumin usage in clinical medicine: tradition or therapeutic? Transfus Med Rev 24: 53-63.

45. Schluster VL, Seldin DW (2004) Renal clearance. In: Seldin DW, Giebisch G, Eds. ThE KIDNEY: Physiology and pathology of New York, Raven Press.

46. Pal R, Ahmed T, Kumar V, Suke SG, Ray A et al., (2009) Protective effects of different antioxidants against endosulfan-induced oxidative stress and immunotoxicity in albino rats. Indian J Exp Biol 47: 723-729.

47. Drimal J, Knezl V, Navarova J, Nedelcevova J, Paulovicova E, et al., (2008) Role of inflammatory cytokines and chemoattractants in the rat model of streptozotocin-induced diabetic heart failure. End Reg 42: 129-135.

48. Maghamiour N, Safaie N (2014) High creatine kinase (CK)-MB and lactate dehydrogenase in the absence of myocardial injury or infarction: A case report. J Card Thoracic Res 6: 69.

49. Hemalatha T, Balachandran C, Manohar B M, Nayeem M, Subramaniam S, et al. (2010) Myocardial expression of PDECGF is associated with extracellular matrix remodeling in experimental myocardial infarction in rats. Biochem Cell Biol 88: 491-503.

50. Tiwari M, Hemalatha T, Ganesan K, Nayeem M, Manohar BM, et al. (2008) Myocardial ischemia and reperfusion injury in rats: Lysosomal hydrolases and matrix metalloproteinases mediated cellular damage. Mol Cell Biochem 312 $81-91$.

51. Radenkovic S, Milosevic Z, Konjevic G, Karadzic K, Rovcanin B, et al. (2013) Lactate dehydrogenase, catalase, and superoxide dismutase in tumor tissue of breast cancer patients in respect to mammographic findings. Cell Biochem Biophys 66: 287-295.

52. Deepa PR, Varalakshmi P (2003) Protective effect of low molecular weight heparin on oxidative injury and cellular abnormalities in adriamycin-induced cardiac and hepatic toxicity. Chem Biol Interact146: 201-210. 